\title{
PENGEMBANGAN MULTIMEDIA INTERAKTIF \\ MENGUNAKAN ADOBE CAPTIVATE 7.0 \\ PADA MATA KULIAH DASAR-DASAR KOMPUTER
}

\author{
Oleh: Nofri Hendri \\ Email: nofrihendritp@gmail.com \\ FIP Universitas Negeri Padang
}

\begin{abstract}
The procedure of this study refers to the development of procedural models Borg \& Gall simplified in accordance with the needs of research. Starting from the Needs Identification, Formulation Objectives, Content Development, Validation, and then do the Revision products according to suggestions and comments matter experts and media experts, the last stage of product trials conducted to 20 students. The analysis showed that the Interactive Multimedia learning media is in the very good category. For material aspects included in the excellent category (4.64). For the aspects of media presentation included in the excellent category (4.58). Furthermore, the test results are limited practicalities of media use are in the very good category (4.4).
\end{abstract}

Keywords: Interactive Multimedia; Adobe Captivate 7.0; Basics Learning Technology.

\section{PENDAHULUAN}

Pendidikan merupakan hal yang sangat berpengaruh terhadap perkembangan dan kemajuan suatu bangsa. Pendidikan merupakan sarana dan wahana yang strategis di dalam pengembangan sumber daya manusia. Oleh karena itu pendidikan harus mendapatkan perhatian yang lebih. Berbagai usaha yang telah dilakukan oleh pengelola pendidikan untuk mengembangkan pendidikan di negara ini dalam rangka meningkatkan prestasi belajar peserta didik dengan mengoptimalkan berbagai sumber daya pendidikan yang tersedia. Tujuan umum pendidikan di masa kini adalah untuk memberi bekal agar kita dapat berfungsi secara efektif di era teknologi ini

Ditinjau dari cara penyajian materi dunia pendidikan menurut Nurjanah (2013: 1) mengalami 4 tahap perubahan. Perkembangan pertama adalah ketika dalam suatu masyarakat tumbuh profesi baru yang disebut guru, yang diberikan tanggung jawab untuk melaksanakan pendidikan mewakili orang tua. Perkembangan kedua dimulai dengan diperkenalkannya bahasa tulisan disamping bahasa lisan dalam penyajian ajaran. Perkembanganketiga terjadi dengan ditemukannya teknik percetakan yang memungkinkan diperbanyak bahan-bahan bacaan dalam bentuk buku-buku teks sebagai materi pelajaran tercetak. Keempat terjadi dengan mulai masuknya teknologi dibidang pendidikan seperti alat-alat mekanis, optis dan elektronis.

Mengajar meliputi segala hal yang pengajar lakukan di dalam kelas. Duffy dan Roehler (1989) dalam Syah (1995:15) mengatakan apa yang dilakukan pengajar agar proses belajar mengajar berjalan lancar, bermoral, dan membuat peserta didik merasa nyaman merupakan bagian dari aktivitas mengajar, juga secara khusus mencoba dan berusaha untuk mengimplementasikan kurikulum dalam kelas. Sementara itu pembelajaran adalah suatu usaha yang sengaja melibatkan dan menggunakan pengetahuan profesional yang dimiliki pengajar untuk mencapai tujuan kurikulum. Jadi pembelajaran adalah suatu aktivitas yang dengan sengaja untuk memodifikasi berbagai kondisi yang diarahkan untuk tercapainya suatu tujuan yaitu tercapainya tujuan kurikulum. 
Fungsi pengajar dalam hal ini yakni sebagai fasilitator, bukan menggurui, sehingga relasi antara pengajar dan peserta didik lebih bersifat Multi Communication. Pengajar dalam hal ini sebagai fasilitator menghubungkan peserta didik dengan materi yang ingin diajarkannya melalui media pembelajaran dengan kemampuan pengelolaan pembelajaran dengan baik sehingga dapat memberikan solusi terhadap kesulitan yang dihadapi peserta didik, seperti yang disampaikan Miarso (2004 : 458) bahwa media pembelajaran adalah:
"Segala sesuatu yang digunakan untuk menyalurkan pesan serta dapat meransang pikiran, perasaan, perhatian dan kemauan peserta didik sehingga dapat mendorong terjadinya proses belajar yang disengaja, bertujuan dan terkendali."

Keterlibatan media pembelajaran dalam proses pembelajaran diharapkan dapat mempengaruhi hasil belajar, semakin kongkrit pembelajaran yang diajarkan dan dirasakan oleh siswa maka pembelajaran semakin efektif. Hal ini senada dengan yang digambarkan oleh Engar Dale.

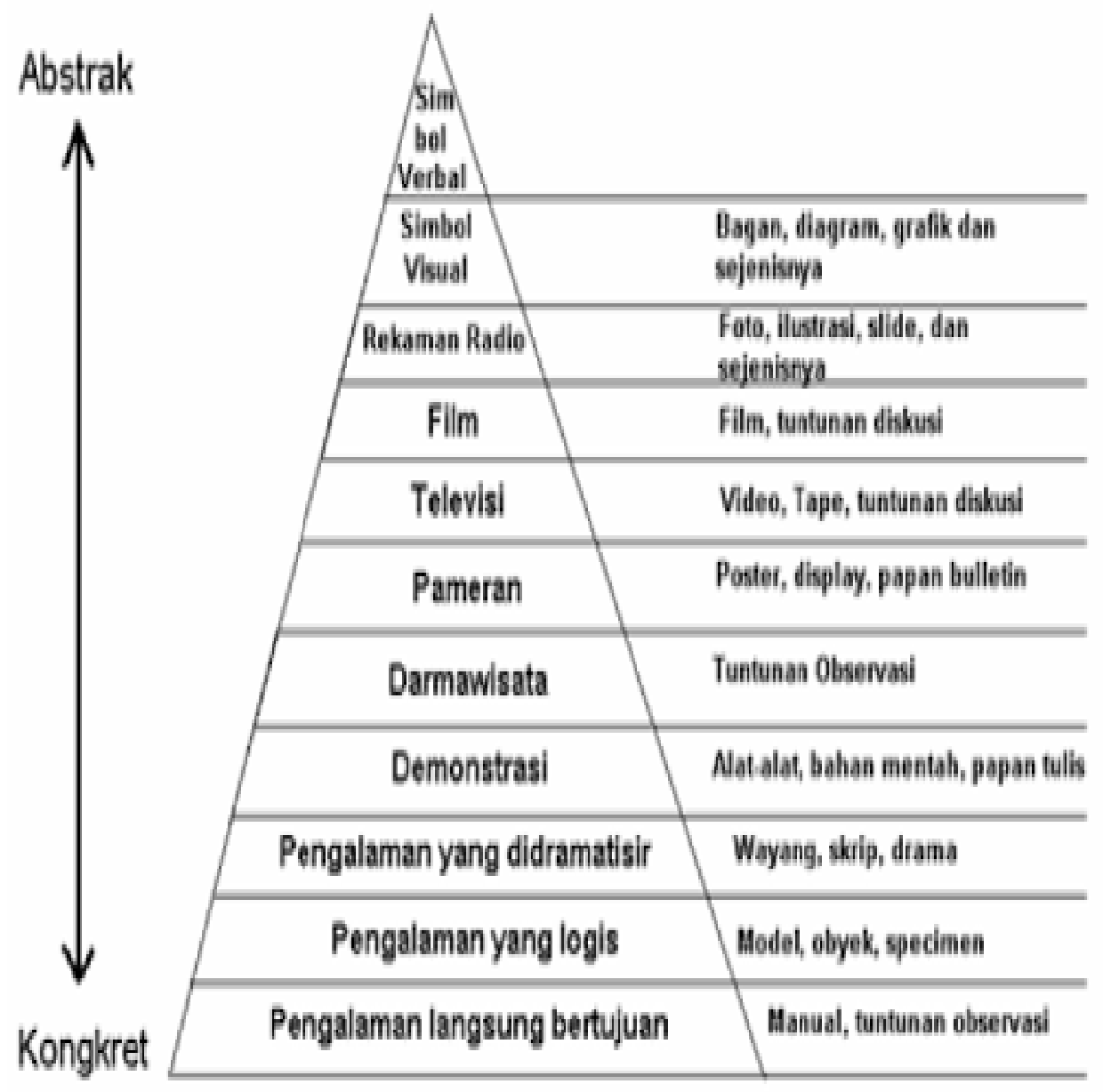

Gambar 1.Dale's Cone of Experience (sumber : Sadiman, 2010)

Pada gambar diatas dapat kita lihat bahwa penggunaan media real object dianggap paling efektif dalam mencapai tujuan pembelajaran. Sehingga mampu mengatasi kesulitan belajar siswa dan perbedaan gaya belajar. Oleh karena itu dengan penggunaan bahan ajar multimedia interaktif sebagai media pembelajaran mampu menampilkan dan menyajikan materi pembelajaran yang lebih konkrit dan mudah dipahami siswa dibanding 
dengan belajar abstrak dengan teknik belajar verbal saja.

Padatnya materi mata kuliah dasar-dasar teknologi pembelajaran dan ketidakhadiran dosen dalam proses pembelajaran membuat penghalang untuk selesainya perkuliahan dengan tepat waktu dan Terbatasnya media pembelajaran berbasis multimedia interaktif juga menyebabkan pembelajaran yang sering kali bersifat monoton. Salah satu software yang dapat membuat berbagai media seperti video, gambar, animasi, suara, dan sebagainya dengan cara mudah adalah Adobe Captivate 7. Dengan bantuan Multimedia Interaktif menggunakan Adobe Captivate 7.0 maka diharapkan dapat menjadi solusi dari permasalahan peserta didik dalam belajar mandiri artinya mahasiswa yang mengambil mata kuliah dasardasar komputer akan dapat belajar sendiri tanpa didampingi oleh seorang dosen dan dapat mengulang pembelajaran tersebut kapanpun.

Adobe Captivate 7.0memiliki banyak fasilitas untuk membuat media pembelajaran seperti: respon interaktif yang cepat, scoring pada akhir program, tampilan materi dan tes interaktif yang beragam, serta managemen konten dalam penggunaan program. Salah satu kelebihan yang dimiliki oleh Adobe Captivate 7.0 dalam hal pembuatannya software yang diciptakan oleh Adobe Systems Incorporated lebih sederhana karena dalam menciptakan programnya seorang programer tidak perlu keterampilan tentang bahasa pemograman dan multimedia.

Berdasarkan uraian latar belakang diatas, maka yang menjadi rumusan masalah dalam penelitian ini adalah bagaimana pengembangan media pembelajaran mutimedia interaktif dengan aplikasi Adobe Captivate 7.0 pada mata kuliah Dasar-Dasar Komputer di Jurusan Kurikulum dan Teknologi Pendidikan Fakultas Ilmu Pendidikan Universitas Negeri Padang yang valid dan praktis?

Adapun tujuan yang ingin dicapai dalam penelitian ini adalah menghasilkan media pembelajaran mutimedia interaktif dengan aplikasi Adobe Captivate7.0 dalam bentuk CD pembelajaran yang valid dan praktis sesuai dengan kriteria kelayakan media.

\section{METODOLOGI PENELITIAN}

Jenis penelitian yang digunakan adalah penelitian pengembangan atau yang lebih dikenal dengan Research and Development (R\&D). Menurut Sugiyono (2012:407) metode penelitian dan pengembangan adalah metode penelitian yang digunakan untuk menghasilkan produk tertentu, dan menguji keefektifan produk tertentu. Penelitian ini menggunakan model prosedural yang diadaptasikan dari model Borg \& Gall yaitu : Identifikasi kebutuhan, Perencanaan/ Perumusan tujuan, Pengembangan format produk awal, Validasi/Uji ahli, dan Revisi.

\section{Identifikasi kebutuhan}

Meliputi kajian pustaka, pengamatan atau observasi, dan persiapanlaporan awal. Mengkaji silabus mata kuliah Dasar-Dasar Komputer.

2. Perencanaan/ Perumusan tujuan

Mencakup merumuskan kemampuan yang akan dicapai mahasiswa, merumuskan tujuan khusus yangingin dicapai oleh produk yang dikembangkan

3. Pengembangan format produk awal

Secara umum pada tahap ini produk awal dirancang dan dikembangkan dimulai dari flowchart, storyboard dan membuat produk.

4. Validasi/Uji ahli

Validasi terhadap model dilakukan oleh ahli yang kompeten dengan menilai draf model. Dalam hal ini yang dilibatkan adalah 2 orang ahli dan 1 orang ahli materi.

\section{Revisi}

Merupakan revisi terhadap draf model yang dilakukan dengan memperhatikan dan menganalisis masukan-masukan yang diperoleh berdasarkan penilaian dan komentar yang diberikan oleh para ahli pada tahapan validasi/uji model

6. Uji Praktikalitas

Setelah dilakukan revisi dari hasil validasi, baik itu uji validasi ahli media dan uji validasi uji materi. Maka tahap selanjutnya adalah 
melakukan tahapan praktikalitas. Pada tahap praktikalitas ini produk multimedia interaktif diuji cobakan kepada 20 orang mahasiswa Teknologi Pendidikan yang telah mengikuti mata kuliah Dasar-Dasar Komputer.

Sedangkan alat pengumpulan data pada penelitian ini adalah sebagai berikut:

a. Dokumentasi, digunakan untuk mendata para ahli, dokumentasi kegiatan validasi

b. Lembaran penilaian, menggunakan format respon lima poin dari Skala Likert, dimana alternatif responnya adalah Sangat bagus/sangat jelas, bagus/jelas, culup/cukup jelas, kurang/kurang jelas, sangat kurang/ sangat tidak jelas, Riduwan, (2010:87).

Setelah data diperoleh tahapan selanjutnya adalah menganalisis data tesebut. Dalam penelitian ini menggunakan analisis deskriptif kuantitatifAnalisis dengan menggunakan variabel, yaitu variabel kualitas multimedia interaktif yang disusun berdasarkan kebenaran dan tampilan yang diperoleh melalui validasi/uji ahli. Sedangkan data berupa komentardan saran dianalisis secara deskriptif kualitatif. Berikut tabel kriteria interprestasi skor yang digunakan untuk menganalisi data yang diperoleh.

Tabel 1. Kriteria Interprestasi Skor

\begin{tabular}{|c|c|l|}
\hline No & Persentase & \multicolumn{1}{c|}{ Kriteria } \\
\hline 1 & $4,1-5$ & Sangat baik \\
\hline 2 & $3,1-4$ & Baik \\
\hline 3 & $2,1-3$ & Cukup baik \\
\hline 4 & $1,1-2$ & Kurang baik \\
\hline 5 & $0-1$ & Sangat tidak baik \\
\hline
\end{tabular}

Sumber : Riduwan (2010: 15)

\section{HASIL PENELITIAN DAN PEMBAHASAN}

\section{Hasil Penelitian}

1. Identifikasi Kebutuhan

Melakukan wawancara kepada beberapa mahasiswa yang telah mengikuti mata kuliah Dasar-Dasar Komputer, dan pada intinya beberapa mahasiswa menginginkan sebuah sumber belajar yang memuat materi dasar-dasar teknologi pembelajaran.

2. Perencanaan/ Perumusan tujuan

Setelah menentukan materi yang akan dikembangkan maka tahap selanjutnya yaitu melakukan perumusan tujuan khusus yang ingin dicapai. Sesuai 4 materi pokok yang akan dikembangkan maka tujuan khusus dari matari mata kuliah yang dikembangkan

3. Pengembangan format produk awal

a. Pengonsepan

Pada tahap pengonsepan penulis merencanakan pembuatan multimedia interaktif pada mata kuliah dasar-dasar teknologi pembelajaran menggabungkan unsur dari teks, animasi, grafis atau gambar, video dan suara atau musik yang nantinya dikemas dalam sebuah media pembelajaran multimedia.

b. Tahap perancangan

Penulis terlebih dahulu merancang flowchart dari produk yang akan dikembangkan

c. Pengumpulan Materi

Tahap pengumpulan materi penulis mengumpulkan materi yang telah ditetapkan untuk dilakukan pengembangan. Pengumpulan materi yang dikembangan merujuk pada tujuan pembalajaran dan referensi yang telah penulis kumpulkan pada tahap sebelumnya

d. Pembuatan

Setelah tahap pengumpulan bahan dilakukan maka tahap selanjutnya yang penulis lakukan adalah tahap pembuatan

4. Validasi

Berikut hasil skor penilaan Ahli Materi dan Ahli Media produk. 
Tabel 2. Hasil Uji aliditas oleh Ahli Materi dan Ahli Media

\section{Skor Rerata}

$\begin{array}{llccr}\text { Aspek } & \text { Kriteria Variabel } & \text { Empiri } & \text { Kategori } \\ & & \text { s } & & \\ \text { Materi } & & & \\ \text { 1. } \text { Kebenaran Konsep } & & & \\ \text { 2. } \text { Kedalaman Materi } & & & \\ & \text { 4. Keakuratan Materi } & 4,61 & 92 \% & \text { Sangat Baik } \\ & \text { 5. Evaluasi } & & & \\ \text { 6. Bahasa } & & & \\ \text { 1. Kemudahan Navigasi } & & & \\ \text { 2. Kandungan Kognisi } & & & \\ \text { Media } & \text { 3. Integrasi Media } & 4,58 & 91,62 \% & \text { Sangat Baik } \\ \text { 4. Presentasi Informasi } & & & \\ \text { 5. Artistik dan Estetika } & & & \\ \text { 6. Fungsi Keseluruhan } & & & \end{array}$

5. Revisi

Revisi yang dilakukan sesuai dengan komentar atau saran dari paraahli yang telah dibuat dalam lembar penilaian. menurut saran ahli materiseperti berikut :

a. Pada menu utama sebaiknya keterangan nama pada tombol navigasi ditampilkan lansung tanpa menggunakan animasi agar mudah mencarinya.

b. Musik instrument pada background sebaiknya dikurangi saat narasi sedang berlansung.

c. Durasi pada video agar lebih diperpanjang, agar informasi pada video dapat diserap lebih baik.

d. Evaluasi pada produk sebaiknya diberikan setiap akhir sub materi Dasar-Dasar Komputer dan dilengkapi petunjuk yang jelas.



Gambar 2. Tampilan Menu Utama Sebelum Dilakukan Revisi 


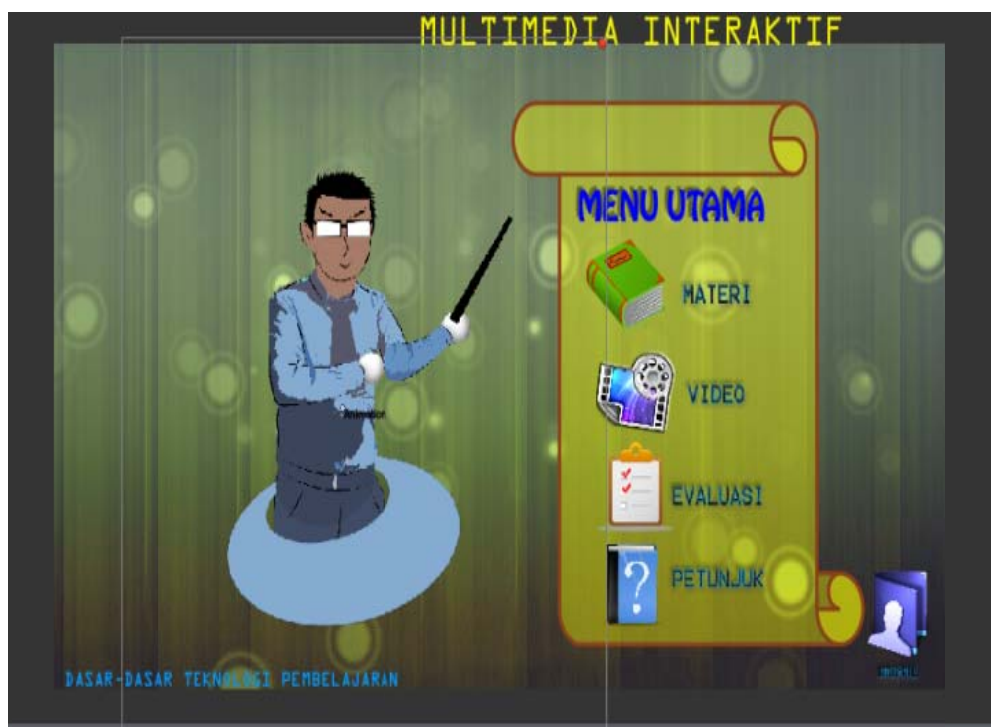

Gambar 3. Tampilan Menu Utama setelah dilakukan Revisi

Selain saran menurut ahli materi, revisi juga dilakukan sesuai saran dari ahli media sebagai berikut: a. Tambahkan gambar atau video yang mendukung pemahaman mahasiswa terhadap materi Dasar-Dasar Komputer.

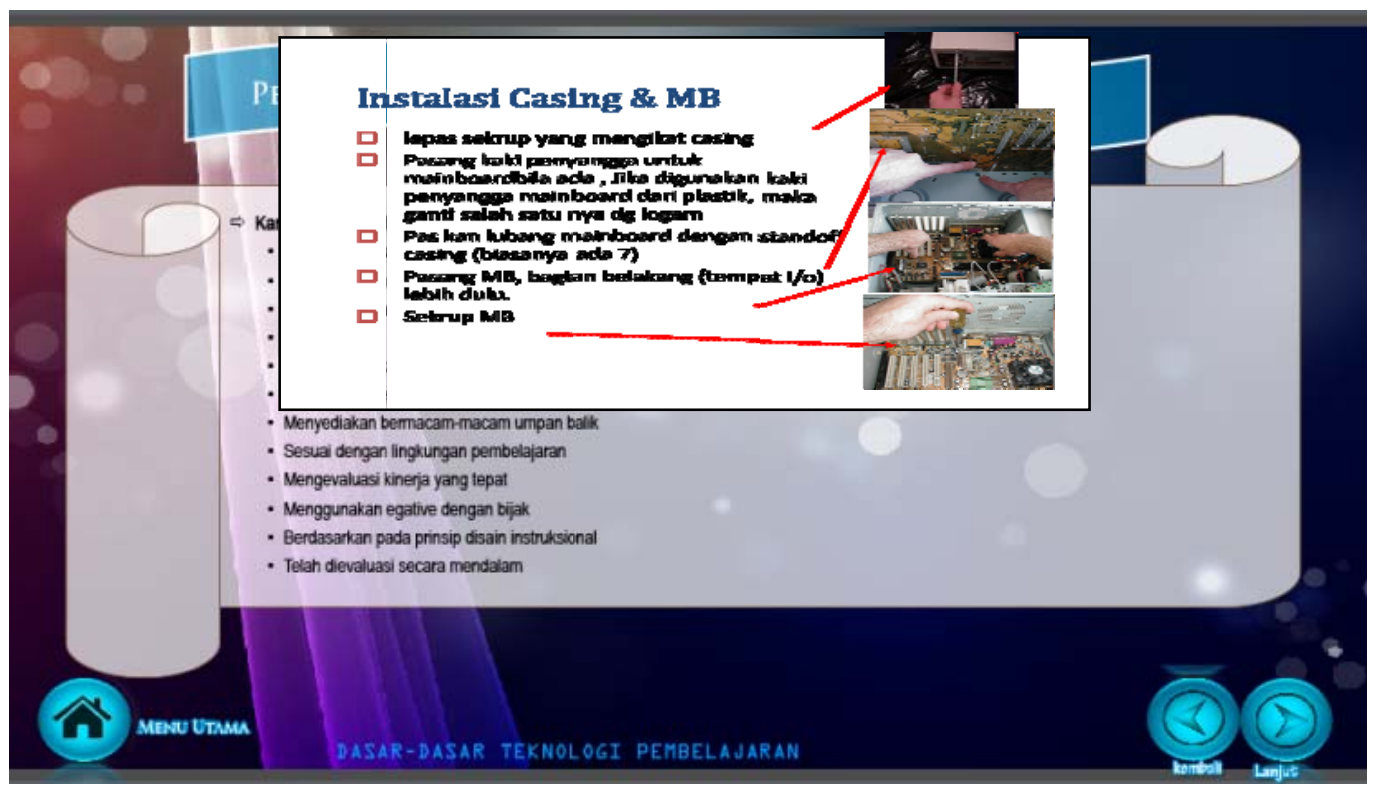

Gambar 4. Tampilan Halaman Materi Sebelum Revisi 


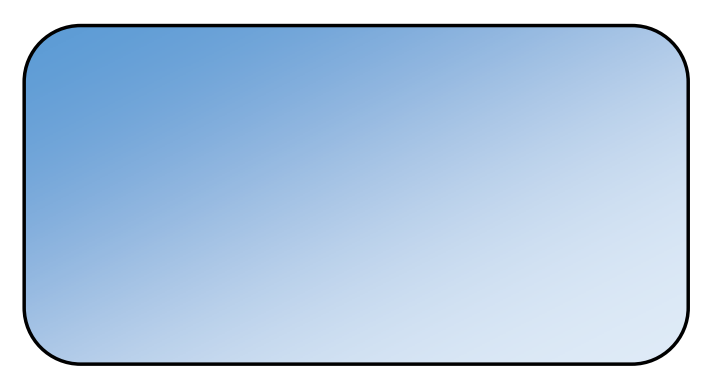

Gambar 5. Tampilan Halaman Materi Sesudah Revisi

b. Durasi video pada saat menampilkan tulisan yang berisikan materi Dasar-Dasar Komputer agar diperpanjang.

c. Tambahkan tombol halaman petunjuk penggunaan pada menu utama. d. Ukuran teks pada materi diperbesar dan warna teks yang digunakan dipilih yang lebih kontras dengan warna background produk Multimedia Interaktif.

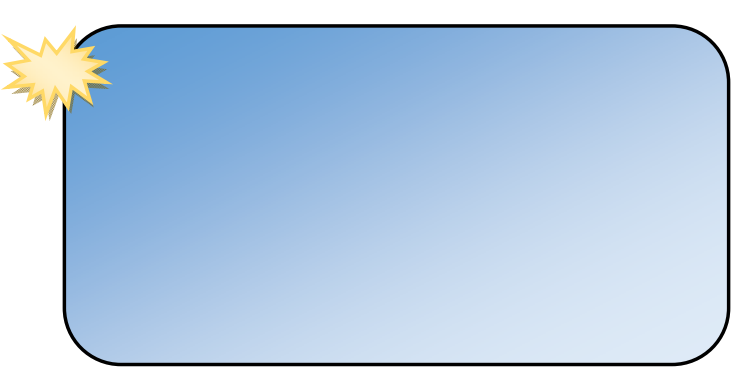

Gambar 6. Tampilan Halaman Materi Sebelum ukuran Tulisan Direvisi 


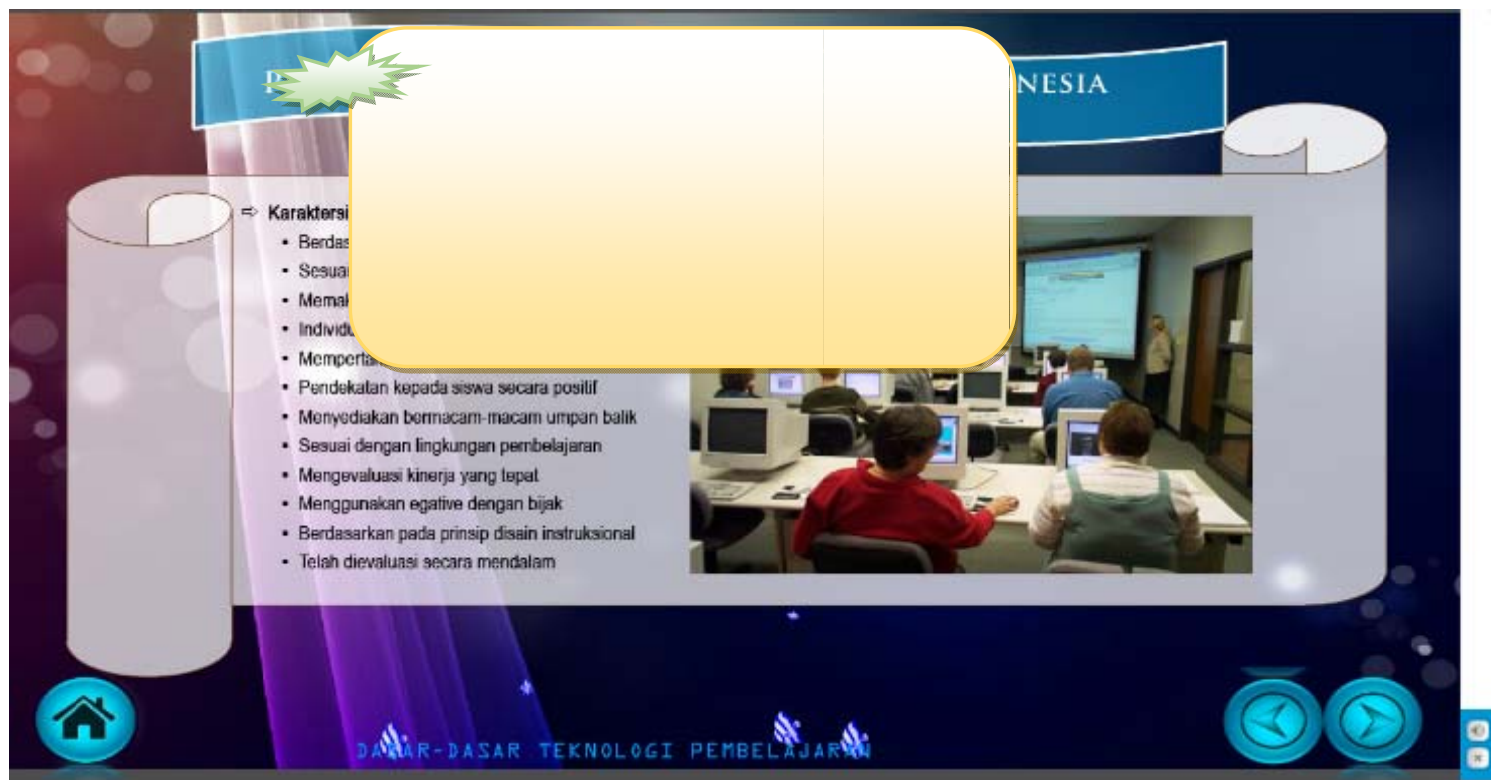

Gambar 7. Tampilan Halaman Materi Sesudah Ukuran Tulisan Direvisi

6. Uji Praktikalitas

Uji Praktikalitas dilakukan kepada 20 orang mahasiswa teknologi pendidikan jurusan Kurikulum dan Teknologi Pendidikan yang telah mengambil mata kuliah Dasar-Dasar Komputer. Berikut skor yang diperoleh dari uji praktilakitas:

Tabel 3. Skor Uji Praktikalitas

\begin{tabular}{|r|l|r|r|r|}
\hline No & Kriteria Variabel & $\begin{array}{c}\text { Skor Tiap } \\
\text { Variabel }\end{array}$ & $\begin{array}{c}\text { Jumlah } \\
\text { Item }\end{array}$ & Rerata \\
\hline 1 & Tampilan & 529 & 6 & 4,4 \\
\hline 2 & Penyajian Materi & 431 & 5 & 4,3 \\
\hline 3 & Isi Materi & 175 & 2 & 4,37 \\
\hline 4 & Evaluasi & 171 & 2 & 4,27 \\
\hline 5 & Kemanfaatan & 454 & 5 & 4,54 \\
\hline & \multicolumn{3}{|c}{} \\
\hline
\end{tabular}

\section{P embahasan}

Kualitas Multimedia Interaktif

Berdasarkan teknik analisis data yang digunakan, maka data yang diperoleh dari tahap validasi oleh para ahli dan uji joba Praktikalitas berupa data kualitatif diubah menjadi data kuantitatif. Data kuantitatif yang dihasilkan kemudian dianalisis tiap aspek penilaian. Skor terakhir yang diperoleh, dikonversi menjadi tingkat kelayakan produk secara kualitatif.

Tabel 4. Hasil Akhir Validitas dan Praktikalitas

\begin{tabular}{|l|l|l|l|l|l|}
\hline \multicolumn{2}{|l|}{ Validitas } & \multicolumn{2}{l|}{ Praktikalitas } \\
\hline Materi & Media & \multicolumn{2}{l|}{ Kelayakan } \\
\hline Rerata & Kategori & Rerata & Kategori & Rerata & Kategori \\
\hline 4,61 & Sangat Baik & 4,58 & Sangat Baik & 4,4 & Sangat Baik \\
\hline
\end{tabular}


a. Penilaian Multimedia Interaktif Dasar-Dasar Komputer

Penilaian multimedia interaktif Dasar-Dasar Komputer dilakukan dengan mengisi instrumen penilaian yang telah disediakan. Lembar penelitian tersebut terdiri dari 3 macam: angket untuk ahli media (22 butir), angket ahli materi (22 butir), dan angket untuk mahasiswa (20 butir) beserta petunjuk pengisisannya. Hasil penilaian berupa data kualitatif kemudian dianalisis untuk menentukan kualitas multimedia interaktif Dasar-Dasar Komputer yang dihasilkan. Skor dari hasil produk multimedia interaktif Dasar-Dasar Komputer yang dikembangkan adalah 4,54 dengan skala 5 dengan presentase sebesar 90,8\% dan mempunyai kualitas Sangat Baik.

b. Penilaian Multimedia Interaktif Dasar-Dasar Komputer dari Tiap Aspek

1) Aspek materi

Aspek materi memperoleh skor rerata sebesar 4,61 dengan presentase $92 \%$ dan berkategori Sangat Baik. Aspekini memiliki 22 butir instrumen dengan 6 aspek penilaian yaitu: (1) Kebenaran Konsep, (2) Kedalaman Materi, (3) Keakuratan, (4) Kengkapan Materi, (5) Evaluasi dan (6) Bahasa. Berdasarkan penilaian dari ahli materi maka mltimedia interaktif ini telah mencakup dari 6 aspek penilaian tersebut. Maka materi yang terdapat pada multimedia interaktif DasarDasar Komputer akan memberikan pengetahuan bagi mahasiswa yang mempelajarinya

2) Aspek Media

Aspek kedua yaitu aspek media memperoleh skor rerata sebesar 4,58 dengan presentase 91,62\% dan berkategori Sangat Baik. Dalam aspek media ini terdiri dari 22 butir instrumen dengan 6 aspek penilaian yaitu: (1) Kemudahan Navigasi, (2) Kandungan Kognisi, (3) Integrasi Media, (4) Presentasi Informasi, (5) Artistis dan Estetika, (6) Fungsi Keseluruhan. Berdasarkan penilaian ahli media secara keseluruhan multimedia ini telah memenuhi 6 aspek penilaian media tersebut. Tampilan program di dalam multimedia interaktif Dasar-Dasar Komputer ini memberikan visualisasi dan kemudahan belajar bagi mahasiswa sehingga dapat meningkatkan minat belajar mahasiswa itu sendiri.

3) Aspek Kelayakan

Aspek ketiga yaitu aspek kelayakan dengan melakukan uji praktikalitas produk yang dikembangkan. Uji coba dilakukan setelah melakukan revisi berdasarkan saran dari ahli materi dan ahli media. Pada aspek kelayakan ini memperoleh skor rerata sebesar 4,4 dengan presentase $88 \%$ dan berkategori Sangat Baik. Dalam aspek kelayakan menggunakan intrumen praktikalitas terhadap produk yang dikembangkan yang terdiri dari 5 aspek praktikalitas yaitu: (1) tampilan, (2) penyajian materi, (3) isi materi, (4) evaluasi, dan (5) kemanfaatan. Berdasarkan uji praktikalitas yang dilakukan oleh mahasiswa, multimedia interaktif yang dikembangkan telah memenuhi aspek kelayakan tersebut. Dengan kemudahan dan kepraktisan multimedia interaktif DasarDasar Komputer, maka dapat membantu mahasiswa dalam meningkatkan minat belajar khususnya mata kuliah Dasar-Dasar Komputer.

\section{SIMPULAN DAN SARAN}

Simpulan

Berdasarkan penelitian pengembangan yang penulis lakukan, maka dapat ditarikkesimpulan :

1. Multimedia Interaktif yang dikembangkan menggunakan aplikasi AdobeCaptivate7.0 dan pengembangan dilakukan pada 4 materi pokok mata kuliah Dasar-dasar Komputer melalui beberapa tahap. Dalam penelitian pengembangan peneliti mengadaptasikan penggunakan model prosedural Borg dan Gall, dimana tahapanya adalah Identifikasi Kebutuhan, Perumusan Tujuan, Pengembangan 
Materi, Validasi, Revisi dan Uji Praktikalitas yang penulis lakukan dengan 20 orang mahasiswa jurusan KTP UNP yang telah mengambil mata kuliah Dasar-Dasar Komputer. Setelah semua tahapan tersebut diselesaikan maka akan jadilah bentuk akhir dari produk multimedia interaktif pada mata kuliah DasarDasar Komputer.

2. Multimedia Interaktif, denganaplikasi Adobe Captivate 7.0 untuk pembelajaran mata kuliah Dasar-Dasar Komputer yang dikemas dalam bentuk CD Pembelajaran initermasuk kedalam kategori Sangat Baik (88\%) dengan jumlah rerataskor sebesar 4,4 (skor maksimum 5). Untuk aspek isi materi programtermasuk dalam kategori Sangat Baik (92\%) jumlah rerata skor sebesar 4,64 (skor maksimum 5). dan kualitas sajian multimedia termasuk dalam kategori Sangat Baik (91,62\%) jumlah rerata skorsebesar 4,58 (skor maksimum 5). berdasarkan Hasil deskriptif data ujiahli.

3. Berdasarkan hasil deskriptif data uji ahli , dan uji Praktikalitas Multimediainteraktif ini layak digunakan sebagi salah satu sumber belajar alternatif dalam matakuliah Dasar-Dasar Komputer.

\section{Saran}

Penelitian ini merupakan penelitian pengembangan multimedia interaktif menggunakan aplikasi Adobe Captivate 7.0 dan dalam penggunaannya menggunakan media komputer.

Adapun saran pemanfaatan dan pengembangan produk tindak lanjut adalah:

\section{Saran Pemanfaatan}

Produk multimedia interaktif ini dapat dijadikan salah satu sumber belajar dalam pembelajaran mata kuliah Dasar-Dasar Teknologi Komputer.

\section{Saran Pengembangan Tindak Lanjut}

a. Bagi mahasiswa yang ingin melakukan penelitian serupa diharapkan untuk dapat memiliki pengetahuan dan keterampilan di bidang IT khususnya program yang digunakan untuk lebih menyempurnakan produk yang dikembangkan

b. Multimedia interaktif pada mata kuliah Dasar-Dasar Komputrer dikemas dalam bentuk CD (Compact Disk) ini juga dapat dikembangkan lebih lanjur dengan menggunakan internet, yaitu dengan menjadikannya sebuah media pembelajaran online (dijadikan Website) sehingga dapat dijangkau luas oleh peserta didik maupun pendidik.

\section{DAFTAR PUSTAKA}

Muhibbin Syah. 1995. Psikologi Pendidikan Suatu Pendekatan Baru. Bandung: Remaja RosdaKarya.

Nurjanah Wijayanti. 2013. "Pengembangan Multimedia Interaktif Berbasis Edutaiment Pada Materi Pokok Thaharah Kelas VII Siswa Smp Muhammadiyah 1 Depok Sleman Yogyakarta." Skripsi tidak diterbitkan: UIN Sunan Kalijaga.

Punaji Setyosari. 2010. Metode Penelitian Pendidikan dan Pengembangan. Jakarta: Kencana Pranada Media Grup.

Riduwan. 2010. Skala Pengukuran Variabelvariabel Penelitian. Bandung: Alfabeta.

Sugiyono. 2011. Metode Penelitian Kuntitatif, Kualitatif dan $R \& D$. Alfabeta: Bandung.

Yusufhadi Miarso. (2007). Menyemai Benih Teknologi Pendidikan: Jakarta. 